\title{
Evaluation of Enset Clones Resistance against Enset Bacterial Wilt Disease (Xanthomonas campestris pv. musacearum)
}

\author{
Tariku Hunduma, Kassahun Sadessa*, Endale Hilu and Mengistu Oli
}

Department of Plant Pathology, Ethiopian Institute of Agricultural Research, Ambo Plant Protection Research Center, Ambo, Post Box 37, Ethiopia

\begin{abstract}
Enset (Ensete ventricosum Welw. Cheesman) is one of the most important staple and co-stable food crops for around 20 million people in Ethiopia. However its production has been threatened by a devastating bacterial disease caused by Xanthomonas campestris pv. musacearum. This disease was officially reported in Ethiopia for the first time in the 1960"s. Therefore, this study was conducted with the objective to screen field-grown Enset clones collected for reaction against bacterial wilt and to assess the farmers practices used for the management of the target pathogen. A large number of Enset clones (20) assessed and collected from the Dire Inchini, Jibat and Wonchi distrcts and were screened against resistance/tolerance to Enset bacterial wilt, $X$. campestris through artificial inoculation. All artificially inoculated Enset clones with $X$. campestris suspensions of different concentration were developed disease symptom of variable intensity levels during the first 30 days after inoculation. The Enset clones, Suite, Warke, Bidu, Astera and Kekari showed $100 \%$ disease symptoms at 30 days after inoculation and could, hence, be used as susceptible checks in future screening trials. This vascular disease was resulted in yellowing of the leaves, wilting and finally collapsing of the entire plant. Disease symptoms were not observed on Enset clones of Mezya, Bedadet, Hiniba and Nech Enset after 90 days of inoculation periods and were taken relatively as resistant to the target wilt causing pathogen. Those Enset clones showed tolerance to Enset bacterial wilt causing pathogen should be multiplied, demonstrated and addressed for the final user or Enset producing farmers and help as one disease management option; in addition to cultural practices and others effective phyto-sanitary measures Enset producing farmers are using.
\end{abstract}

Keywords: Ensete ventricosum; Bacterial wilt; Resistance; Susceptibility

\section{Introduction}

Enset, Ensete ventricosum is a perennial, herbaceous and a monocarpic, crop, belonging to the family musaceae and the genus Ensete [1]. It is commonly known as "false banana" for its close resemblance to the domesticated banana plant. About 25 species of Ensete are equally distributed in Asia and Africa [2]. Among these species, E. ventricosum is widely grown in Ethiopia and is a traditional staple food crop for over 20 million people in the South and South West parts of the country. It is estimated that about 146 thousand hectares in Southern Nations, Nationalities and Peoples Regional State (SNNPRS) and 79 thousand hectares in Oromia are covered with Enset [3]. Enset can grow in a wide range of altitude, however the best elevation for its cultivation is between 2000 and $2750 \mathrm{~m}$. a. s. 1 with an average annual rainfall of 1100 to $1500 \mathrm{~mm}$ [4]. The crop can withstand relatively long period of drought (about 5 months). The average temperature of Enset growing areas is between 10 and $21^{\circ} \mathrm{C}$ and a relative humidity of 63 to 80 percent [4]. The ideal soils for Enset cultivation are moderately acidic to alkaline ( $\mathrm{pH}$ of 5.6 to 7.3) [5]. Enset grows well in most of the soil types, if they are sufficiently fertile and well drained. Cattle manure is used as the main organic fertilizer. It prefers nitosols than vertisols $[4,6]$.

Enset is a drought tolerance and multi-purpose crop; it makes major contribution to the food security scheme of the country. All plant parts of Enset are utilized for different purposes. The parts of Enset used as food vary from region to region. Enset is used as food in three forms: amicho, kocho and bulla. Enset is attractive to farmers because its ability to produce more food than other cultural crops on a small piece of land with minimum inputs [7]. Enset provides fiber as a byproduct of decorticating the leaf-sheaths. Enset fiber accounts for more than $30 \%$ of the Ethiopian fiber production and its strength is equivalent to the fiber of Abaca [4]. Enset products are available throughout the year and can be stored in pits for long periods of time without spoiling. Fresh Enset leaves are used as bread and food wrappers, cattle feed, serving plates and pit liners for store kocho for fermentation [4]. Enset is rich in carbohydrate and mineral substances like calcium and iron [8]. Enset plantations prevent soil erosion and conserve soils, hence, contributing to the sustainability of the farming system [9]. Regions where Enset is used as staple or co-staple food are usually less affected by the recurrent drought periods that occur in Ethiopia [10]. However, there are lots of biotic and abiotic problems threatening Enset production [10]. Among the biotic constraints, diseases caused by bacteria, fungi, nematodes and viruses; mammalian pests such as porcupine, mole rat, wild pig and insect pests such as mealy bugs have been identified as serious problems. Of all the biotic constraints, bacterial wilt disease, which is caused by Xanthomonas campestris pv. musacearum $(\mathrm{Xcm})$ is the most important disease affecting yield [11]. Enset bacterial wilt is known to cause severe damage, as it attacks and kills the plants at any growth stages, including full maturity (ready for harvest). Once the plants are attacked by the disease, especially at late maturity stage, it affects whole systems, and usually causing a maximum yield loss. A serious outbreak

*Corresponding author: Kassahun Sadessa Biratu, Plant Pathologist (MSc.), Researcher and Quality, Agricultural Research Representative, Ethiopian Institute of Agricultural Research, Ambo Plant, Protection Research Center P. O. X : 37, Ambo, Ethiopia, Tel: 251-0912288938, 251-0112362036; E-mail: ksbsedessa@yahoo.com

Received October 18, 2014; Accepted April 28, 2015; Published April 30, 2015

Citation: Hunduma T, Sadessa K, Hilu E, Oli M (2015) Evaluation of Enset Clones Resistance against Enset Bacterial Wilt Disease (Xanthomonas campestris pv. musacearum). J Veterinar Sci Technol 6: 232. doi:10.4172/2157-7579.1000232

Copyright: @ 2015 Hunduma T, et al. This is an open-access article distributed under the terms of the Creative Commons Attribution License, which permits unrestricted use, distribution, and reproduction in any medium, provided the original author and source are credited. 
of the disease was reported by Westphal [1] with losses up to $70 \%$. The results obtained from recent bacterial wilt disease assessment made in some Enset fields of the SNNPR, showed losses of up to $100 \%$ under severe damage [12]. Many researchers [13-15] reported that both the area and productivity of Enset is declining continuously due to this disease.

Brandt et al. [4] reported that the only recommended control measures for the bacterial wilt of Enset are cultural practices which include the use of healthy, disease-free suckers for planting material, destruction and controlled movement of diseased plants, cleaning of equipment that has come in contact with diseased plant material and rotation of crops. Although the phytosanitary approaches currently being recommended are labors intensive and not easily adopted by farmers they are presently the only known means of preventing further spread of the epidemic until more sustainable management options are available. Enset bacterial wilt can effectively be controlled by growing of resistant varieties. Thus, this study was initiated to screen and provide Enset clones relatively resistant to Enset bacterial wilt disease in Ethiopia.

Therefore, the objectives this research works:

- To screen and evaluate Enset clones resistance to Enset bacterial wilt disease and

- To assess the farmerse practices used for the management of Enset bacterial wilt.

\section{Materials and Methods}

\section{Collection of diseased Enset samples and clones}

Diseased Enset Samples and Clones were collected from the major Enset growing districts west and south west zones of Oromiya region, Ethiopia viz., Tikur Inchini, Wanchi, Waliso and Jibat districts. Both diseased Enset samples and young health clones were collected from five kebeles in each district in random sample form. The clone collected was about one year old. Additionally, Enset field, supplementary information's (like clone type, date of collection, elevation, latitude and longitude, field history, plant growth stages, etc.) was recorded. The samples were labeled properly and brought into Ambo Plant Protection Research Center for further studies.

\section{Isolation of $X \mathrm{~cm}$}

The pathogen, Xanthomonas campestris pv. musacearum, was isolated from Enset plant parts (petioles and midrib leaves) by growing on the selective media i.e. Yeast Dextrose Calcium Carbonate (YDC) agar media (yeast $10 \mathrm{~g}$, dextrose $20 \mathrm{~g}$, calcium carbonate $20 \mathrm{~g}$ and agar 15-20 g per $1000 \mathrm{ml}$ of sterile distilled water, when targeted to prepared one litre). Calcium carbonate was added after cooling of the other ingredients. Diseased Enset saples were surface sterilized by $1 \%$ sodium hypochlorite ${ }^{\text {ees }}$, crashed and streaked on solid surface of YDC plates and incubated at $28^{\circ} \mathrm{C}$ for about one to three days as done by Blanchard and Talter [16]. After 48 to 72 hours of incubation, colonies showed light yellow mucoid growth, typical of $X \mathrm{~cm}$ was transferred to YDC broth and preserved with $20 \%$ glycerol and maintained at $4^{\circ} \mathrm{C}$ in refrigerator for further studies [17].

\section{Biochemical characterization of the pathogen, $X \mathrm{~cm}$}

The biochemical test includes; $\mathrm{KOH}$ solubility test, Oxidase, Catalase, Starch hydrolysis and Tween 80 hydrolysis were made and the characters were recorded for each test.
KOH solubility test: The KOH solubility test was performed by the method of Fahy and Hayward [18] using $24 \mathrm{~h}$ culture. Two drops of $3 \% \mathrm{KOH}$ were put onto glass slide and the $\mathrm{Xcm}$ colony was stirred into the solution with clean loop for $10 \mathrm{~s}$. When the solution was viscous enough to stick to the loop causing a thin strand of slime, then the test was recorded as $\mathrm{KOH}$ soluble positive or not.

Oxidase test: Oxidase activity was detected by the method of Kovacs [19]. Freshly grown $24 \mathrm{~h}$ cultures from YDC agar media with $1 \%$ glucose were patched onto a filter paper moistened with a fresh oxidase reagent $(1 \% \mathrm{w} / \mathrm{v}$ aqueous solution of tetramethyl-paraphenylene diamine dihydrochloride) using a wooden stick. A purple reaction in $30 \mathrm{~s}$ was recorded as oxidase positive [20].

Catalase test: Catalase test were performed according to methods described by $\mathrm{He}$ et al. [21]. One $\mathrm{ml}$ of a $3 \%$ solution of hydrogen peroxide was added to a Petri dish and a loop of fresh culture grown on YDC agar medium were rubbed into the solution. Release of bubbles from the culture was recorded as catalase positive [20].

Tween 80 hydrolysis: Fatty acid esterase activity was tested by streaking the bacteria onto a nutrient agar medium containing calcium chloride and Tween 80, a polymer consisting of polyoxyethylene-sorbitanmonooleate as stated by Sands [20]. The medium contains: peptone, $10 \mathrm{~g}$; $\mathrm{CaC} 12$ dihydrochloride, $0.1 \mathrm{~g}$; NaCl, $5 \mathrm{~g}$; agar, $15 \mathrm{~g}$; distilled water, $1 \mathrm{l}$; with the $\mathrm{pH}$ adjusted to 7.4. Tween 80 were autoclaved separately and added with $10 \mathrm{ml} / 1$ and mixed before plating.

Incubation was made at $30^{\circ} \mathrm{C}$ for up to 7 days [18]. An opaque zone of crystals around a colony was recorded as positive reaction for hydrolysis of Tween 80 .

Starch hydrolysis: Nutrient agar plates containing $0.2 \%$ soluble starch $(\mathrm{w} / \mathrm{v})$ was streaked by the test Enset bacterial strains and incubated at $30^{\circ} \mathrm{C}$ until heavy growth occurred. Then plates were flooded with IKI solution (iodine, $1 \mathrm{~g}$; potassium iodide, $2 \mathrm{~g}$; distilled water, $100 \mathrm{ml}$ ). A clear zone around a colony was recorded as positive reaction. Based on the Bergey's Manual of Systematic Bacteriology, the bacterial isolate, $X c m$ was confirmed and identified [22].

\section{Screening of Enset clones for resistance against $\mathrm{Xcm}$}

Screening of Enset clones for resistance to $\mathrm{Xcm}$, the one year old young clones of each of the twenty genotypes (Table 1) were used and planted on PVC pots $(30 \mathrm{~cm}$ in diameter and $30 \mathrm{~cm}$ height) filled with $6 \mathrm{~kg}$ of sterilized mixture of top soil, manure and sand of 3:2:1 ratio (Figure 1).

Single clone was planted per pot (three clones per genotype represent for a replication) and each treatment was replicated three times in a Randomized Complete Block Design (RCBD). The total numbers of clones planted were 180. Enset clones of Meziya and Suite of nearly having one year old was used as a resistant and susceptible check, respectively. Bacterial suspension was prepared from pure culture of $X \mathrm{~cm}$ for artificial inoculation. The cells of the suspensions of $1 \times 10^{7}$ and $1 \times 10^{8} \mathrm{cfu} / \mathrm{mL}$ were used. Bacterial suspension of $3 \mathrm{ml}$ ( 1 day old) was used for inoculation of the clones. Five $\mathrm{ml}$ capacity of sterile hypodermic syringe with metal needle was used to inject the bacterial suspension into the petiole of the youngest open leaf. The same quantity of sterile water was injected into control plants. Plants incubated under field conditions and were monitored for 12 weeks. The observation for symptom development was made at five days interval after inoculation. The presence of bacterial ooze and discolored vessels was checked by cutting the inoculated leaf petiole close to pseudo-stem. 
Citation: Hunduma T, Sadessa K, Hilu E, Oli M (2015) Evaluation of Enset Clones Resistance against Enset Bacterial Wilt Disease (Xanthomonas campestris pv. musacearum). J Veterinar Sci Technol 6: 232. doi:10.4172/2157-7579.1000232

\begin{tabular}{|c|c|c|c|c|}
\hline No & Clones Name & District & Collection site & Altitude m. a. s. I. \\
\hline 1 & Warqee lja & Tikur Inchini & Bola germama & 2577 \\
\hline 2 & Hadha Bishan & Tikur Inchini & Bola Germama & 2572 \\
\hline 3 & Hadha Bala & Tikur Inchini & Bola Roge & 2582 \\
\hline 4 & Garda Gababa & Jibat & Bilo Malima & 2102 \\
\hline 5 & Bedadet & Tikur Inchini & Bola Roge & 2102 \\
\hline 6 & Sabbara & Tikur Inchini & Bola Roge & 2582 \\
\hline 7 & Warke Bidu & Tikur Inchini & Bola Geramama & 2577 \\
\hline 8 & Hiniba & Tikur Inchini & Bola Demake & 2569 \\
\hline 9 & Ferasiye & Jibat & Munyo Witate & 2102 \\
\hline 10 & Kekar & Tikur Inchini & Bola Roge & 2102 \\
\hline 11 & Astera & Tikur Inchini & Bola Demake & 2569 \\
\hline 12 & Abba Jobir & Jibat & Tutu Jibat & 2569 \\
\hline 13 & Warke Adi & Tikur Inchini & Bola Roge & 2102 \\
\hline 14 & Awegene & Tikur Inchini & Bola Germama & 2564 \\
\hline 15 & Warke Dima & Tikur Inchini & Bola Germama & 2577 \\
\hline 16 & Garda Dhera & Tikur Inchini & Bola Roge & 2102 \\
\hline 17 & Shartiye & Tikur Inchini & Bola Roge & 2582 \\
\hline 18 & Awenyi & Tikur Inchini & Bola Germama & 2564 \\
\hline 19 & Suite & & Areka & \\
\hline 20 & Meziya & & Areka & \\
\hline
\end{tabular}

Table 1: List of Enset clones, districts, collection sites and an altitude for evaluation of Enset clones resistance to $X c m$.

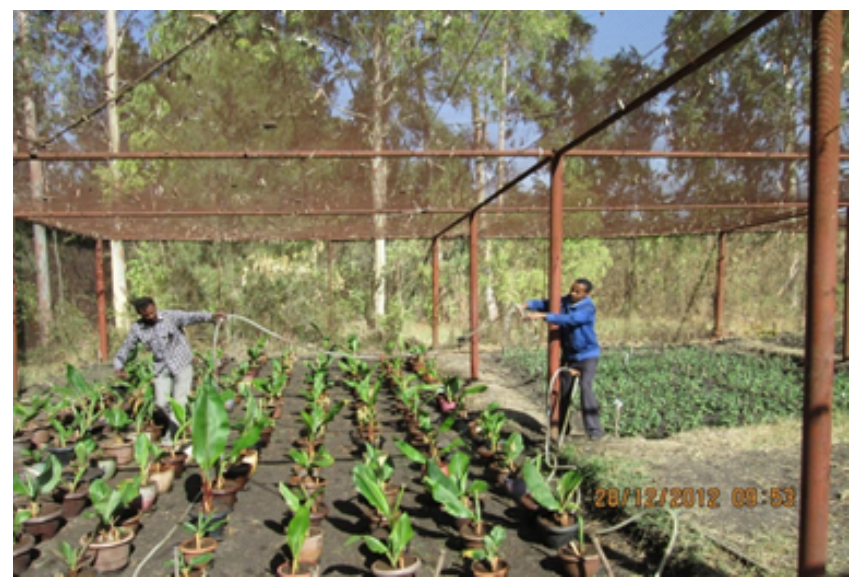

Figure 1: Screening of Enset clones resistance against artificial inoculation of Enset bacterial wilt under pot culture condition.

Re-isolation of the pathogen was made from infected leaf petiole and sheaths of inoculated plants. Disease assessment was done at $8,13,18$, $23,28,33,38$ to 90 days (five days intervals) after inoculation. The data was recorded on disease incubation on each plant of each clone. The number of infected plants per clone at each disease assessment period was recorded. Disease severity was assessed on whole plant basis of number of wilted leaves using the following scale is developed viz., 0 : no symptoms; $1: 1$ inoculated leaf wilted; 2:2-3 leaves wilted; 3:4 leaves wilted; 4: all leaves wilted and 5: plant dead. The data was analyzed by using SAS programme [23].

\section{Assessment of farmer's practices towards the management of Enset bacterial wilt}

From each district, major Enset growing localities survey was conducted to get supplementary information and practices used for the management of Enset bacterial wilt based on questionnaire and interviews. Based on farmers interviewed at different localities, Enset farmers were practices used for the management of Enset bacterial wilt i.e., avoiding source of inoculum, field rotation, protecting animals ${ }^{\text {ee }}$ interferences and phytosanitary practices in implements utilization.

\section{Data analysis}

The incidence and prevalence data were analyzed by using the descriptive statistical analysis (mean) and were presented in tables and graphs. The statistical differences for resistance among Enset clones; the disease severity means for the various genotypes were analysed on one way ANOVA using SAS version 9.1 [23] by using Duncan"s Multiple Range Test (DMRT).

\section{Results and Discussion}

\section{Isolation and identification of $\mathrm{Xcm}$}

EBW disease samples were taken from infected plant parts of Enset leaf petioles, corm and pseudo-stem showing discoloration of plant tissue with large air pocket filled with creamy or yellowish exudates (ooze) (Figure 2). The bacterial ooze sign sample was collected from Waldo Hindhe locality, Tikur Inchini district. SAS [24] also reported that the similar yellow bacterial ooze exudates come out from the cut pseudo stem and leaf petioles of Enset plants.

Under laboratory condition, the samples were cultured on YDC solid plates and the culture was observed after 72 hours of incubation; bacterial colonies were developed a light yellow, circular, high convex, dome shaped and shiny appearance of mucoid colonies (Figure 3 ). The similar results were also reported by Tsehay [25], that bacterial isolates of Enset grown on YDC agar culture plates produced creamy, yellow, and light yellow mucoid circular colonies with dome shaped and shiny appearance.
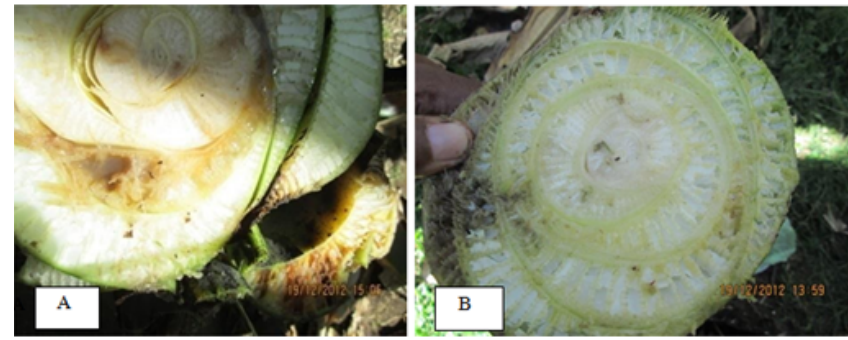

Figure 2: (A) Enset pseudo-stem with bacterial ooze (B) Healthy Enset pseudo-stem.
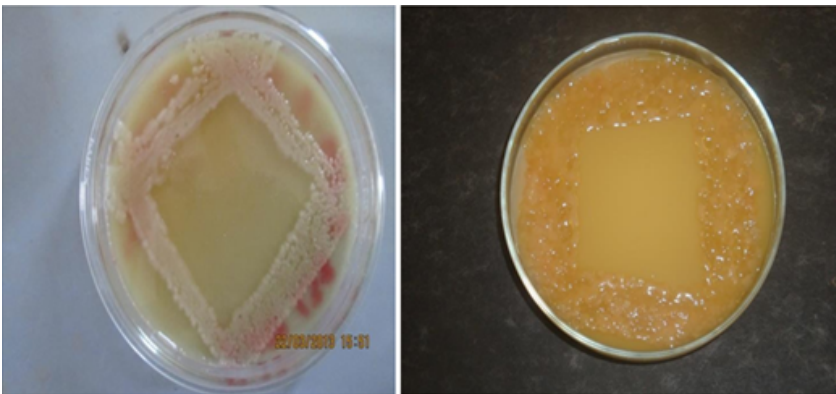

Figure 3: Pure colonies of $\mathrm{Xcm}$ on NA (first) and YDC (second) solid plate media. 
Citation: Hunduma T, Sadessa K, Hilu E, Oli M (2015) Evaluation of Enset Clones Resistance against Enset Bacterial Wilt Disease (Xanthomonas campestris pv. musacearum). J Veterinar Sci Technol 6: 232. doi:10.4172/2157-7579.1000232

\section{Biochemical characterization of Enset bacterial isolates}

Generally the Enset bacterial Isolates were positive to $\mathrm{KOH}$ solubility test, oxidase test, catalase test, and starch hydrolysis and negative to Tween 80 hydrolysis.

KOH solubility test: The $\mathrm{KOH}$ solubility test was recorded as $\mathrm{KOH}$ soluble positive which is similar as the method of Fahy and Hayward [18] using $24 \mathrm{~h}$ culture (Figure 4).

Oxidase test: Oxidase activity was detected by the method of Kovacs [19], Sands [20] and become positive to the test.

Catalase test: Catalase test for the cultures were performed according to methods described by $\mathrm{He}$ et al. [21] and the test was remain positive to the test.

Starch hydrolysis: A clear zone around a colony made was recorded as positive reaction to the starch hydrolysis.

Tween 80 hydrolysis: Fatty acid esterase activity was tested was result to negative response/reaction as per the Sands [20] method. An opaque zone of crystals around a colony was not formed and recorded as negative reaction for hydrolysis of Tween 80 which is similar result with the test method of Fahy and Hayward [18]. Finally based on the Bergey's Manual of Systematic Bacteriology, the Enset bacterial wilt isolates were identified as Xanthomonas campestris pv musacearum (Xcm).

\section{Evaluation of Enset clones for resistance to $\mathrm{Xcm}$ pathogen}

Enset clones collected were screened against Enset bacterial wilt pathogen, Xanthomonas campestris pv. musacearum (Xcm) using artificial inoculation under pot culture condition at Ambo Plant Protection Research Center, Ambo, Ethiopia (Figure 5). The clone Meziya was used as positive control or resistance and Suite negative check or susceptible.

The relative resistance and susceptibility of Enset clones to Enset bacterial wilt was evaluated three months after inoculation based on wilt incidence and pathogen incubation period till it develop symptoms. Disease evaluation data was recorded at 7 days interval for 3 months. The first symptoms of disease on infected clones were yellowish of central leaf at the apex and wilting. Average disease incidence as measured by percent infected and/or dead Enset plants, which showed varied differences among test clones at different disease assessment period after inoculation. All Xcm inoculated Enset clones developed disease symptoms to various intensity levels after 15 to 30 days inoculation (Figure 6). However, several Enset clones showed relative tolerance to the disease. A difference in progression of the disease also was apparent. In all disease assessment periods, the ranges of disease incidence were variable ranging from 20 to $100 \%$ or total death of some Enset clones were observed. Re-isolation of the pathogen was done and there was no bacterial colonies in Enset clones remain tolerant to $\mathrm{Xcm}$. Out of the 20 Enset clones, only 6 Enset clones showed a mean disease incidence of less than 50 percent. Some of the clones were more severely affected within shorter period of time than others. But there is no significant difference between Enset clones artificial inoculated from bacterial suspension concentration of @1 $1 \times 10^{7}$ and $1 \times 10^{8} \mathrm{cfu} /$ $\mathrm{ml}$ the development of symptoms and incidence into the clones showed the disease incidence was not variable. The Enset clones, Warke bidu, Awenyi, and Kekar showed $100 \%$ disease symptoms at 30 days after inoculation and could, hence be used as susceptible checks in future screening trials. Disease symptoms were observed on Meziya, Hineba, Bedadet and Warke Dima between 21 and 30 days after inoculation.

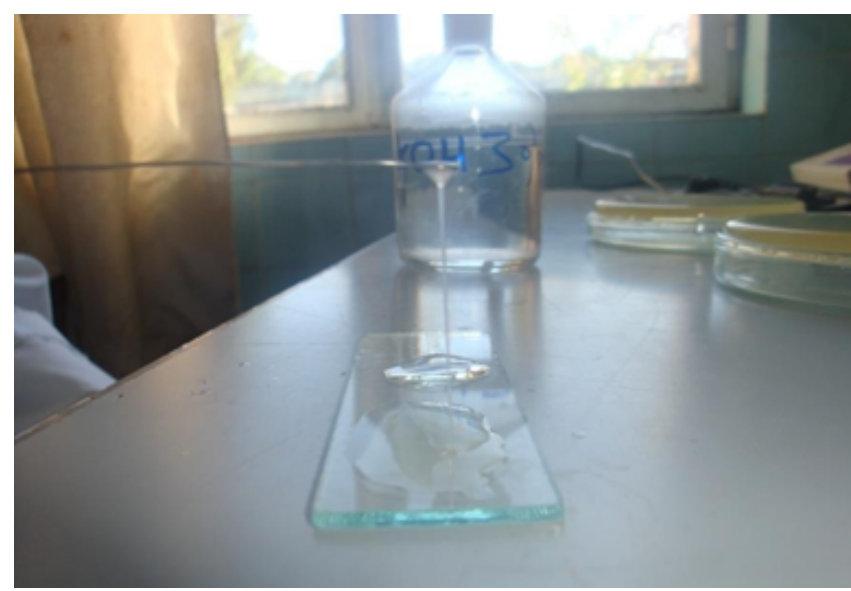

Figure 4: $\mathrm{KOH}$ solubility test response of pure culture of Enset $\mathrm{Xcm}$.

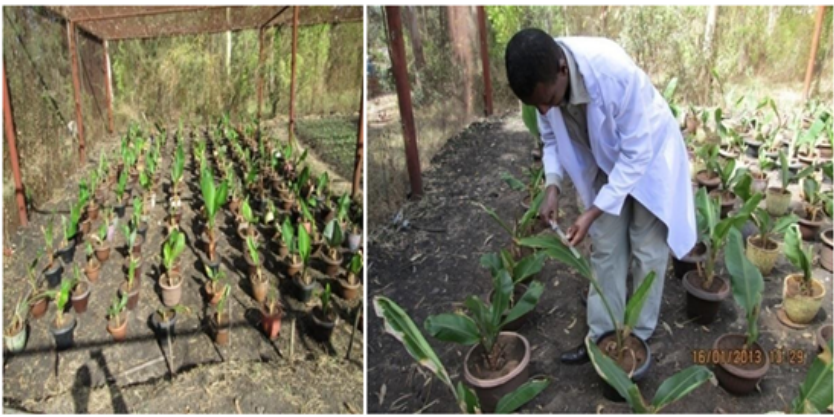

Figure 5: Artificial inoculation of Enset clones by EBW Pathogen.
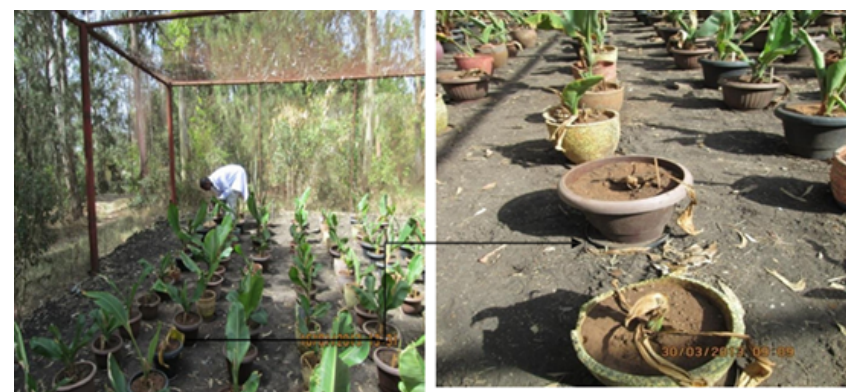

Figure 6: Disease symptoms developed, resistant and susceptible Enset clones total death.

These clones were the immune clones throughout the evaluation period. The remaining Enset clones were relatively resistant/tolerant after inoculation of Xcm (Table 2). Among all "Meziya" was found to have the lowest percentage of disease incidence (19.31\%) followed by "Hiniba" (30.18\%) and "Bedadet" (34.26\%). Based on the evaluation of their reaction, none of the Enset clones had complete resistance to $\mathrm{Xcm}$. These results are in accordance with the earlier reports of "Meziya" that was considered as better tolerant clone [26-28]. In the present study, the Enset clones, "Meziya", "Hineba", "Bedadet" and "Warke Dima" clones were exhibited better tolerance to the bacterial wilt, under artificial inoculation conditions @ both $10^{7}$ and $10^{8}$ dilutions/concentration. Hence, "Meziya”, "Hineba”, "Bedadet” and "Warke Dima” Enset clones 


\begin{tabular}{|c|c|c|c|c|c|}
\hline \multirow[b]{2}{*}{ No } & \multirow{2}{*}{$\begin{array}{l}\text { Treatment or } \\
\text { Enset clones }\end{array}$} & \multirow{2}{*}{$\begin{array}{c}\text { Number of leaves } \\
\text { per clone before } \\
\text { inoculation }\end{array}$} & \multicolumn{3}{|c|}{ Number of leaves wilted } \\
\hline & & & DWISD\%* & NWLIS\%* & TLW\%* \\
\hline 1 & Warke lja & 7 & $15.333^{d}$ & $24.41^{\mathrm{ab}}$ & $54.762^{\mathrm{abc}}$ \\
\hline 2 & Hadha Bishan & 3 & $20.889^{\mathrm{bcd}}$ & $37.96^{\mathrm{ab}}$ & $57.408^{\mathrm{abc}}$ \\
\hline 3 & Hadha Bala & 4 & $28.667^{a b}$ & $26.85^{\mathrm{ab}}$ & $43.518^{\text {bcde }}$ \\
\hline 4 & Garda Gababa & 3 & $29.222^{\mathrm{ab}}$ & $39.82^{\mathrm{ab}}$ & $53.704^{\mathrm{abcd}}$ \\
\hline 5 & Bedadet & 4 & $23.667^{\mathrm{abcd}}$ & $18.52^{\mathrm{b}}$ & $34.260^{\text {def }}$ \\
\hline 6 & Sabara & 4 & $20.889^{\text {bcd }}$ & $38.89^{\mathrm{ab}}$ & $58.333^{\mathrm{abc}}$ \\
\hline 7 & Warke Bidu & 4 & $15.889^{d}$ & $44.26^{a}$ & $66.667^{a}$ \\
\hline 8 & Hiniba & 4 & $30.3334^{a}$ & $27.59^{\mathrm{ab}}$ & $30.186^{\text {ef }}$ \\
\hline 9 & Feresiye & 3 & $19.222^{\text {cd }}$ & $42.59^{a b}$ & $53.703^{\mathrm{abcd}}$ \\
\hline 10 & Kekar & 3 & $17.556^{\mathrm{cd}}$ & $31.48^{\mathrm{ab}}$ & $66.667^{a}$ \\
\hline 11 & Astera & 4 & $26.444^{\mathrm{abc}}$ & $31.85^{\mathrm{ab}}$ & $57.963^{\mathrm{abc}}$ \\
\hline 12 & Aba Jobir & 3 & $23.111^{\mathrm{abcd}}$ & $38.89^{\mathrm{ab}}$ & $46.297^{\text {abcde }}$ \\
\hline 13 & Warke Adi & 4 & $25.889^{\mathrm{abc}}$ & $30.55^{\mathrm{ab}}$ & $51.851^{\mathrm{abcd}}$ \\
\hline 14 & Awegene & 3 & $21.444^{\mathrm{abcd}}$ & $34.26^{\mathrm{ab}}$ & $61.111^{\mathrm{ab}}$ \\
\hline 15 & Warke Dima & 5 & $29.222^{\mathrm{ab}}$ & $38.33^{\mathrm{ab}}$ & $40.000^{\text {cde }}$ \\
\hline 16 & Garda Dhera & 3 & $18.111^{\mathrm{cd}}$ & $33.33^{\mathrm{ab}}$ & $57.407^{\mathrm{abc}}$ \\
\hline 17 & Shartiye & 3 & $15.333^{d}$ & $34.26^{\mathrm{ab}}$ & $63.889^{\mathrm{ab}}$ \\
\hline 18 & Awenyi & 4 & $15.889^{d}$ & $32.41^{\mathrm{ab}}$ & $66.667^{a}$ \\
\hline 19 & Suite & 5 & $19.222^{\text {cd }}$ & $29.07^{\mathrm{ab}}$ & $57.037^{\mathrm{abc}}$ \\
\hline 20 & Meziya & 7 & $29.778^{\mathrm{ab}}$ & $19.31^{b}$ & $19.311^{f}$ \\
\hline
\end{tabular}

NB: Mean with the same letter is not significantly different.

*DWISD: Date of Wilted Initial Symptoms Development. *NWLIS: Number of Wilted Leaves Initial Symptoms. *TLW: Total Leaves Wilted.

Table 2: Percentage of plants for the different Enset clones developing disease symptoms after artificial inoculation with $\mathrm{Xcm}$.

should be considered as most tolerant/resistant clones to the pathogen and these four clones could be used as a bacterial wilt management component. Developing and use of resistant/tolerant Enset clones is one of the best approaches in the management of EBW, cheaper to the farmers and safer to environment similarly, variable levels of clonal response against the $X \mathrm{~cm}$ disease have been observed under farmer's field conditions and using artificial inoculation in on station trials by Welde-Michael [11] and Anita et al. [13].

\section{Farmer's practices towards management of Enset bacterial} wilt

The assessed farmers practices on the management of EBW disease were totally related to sanitary measurements. The survey result was indicated that, only about $40 \%$ of respondent farmers in all sampled kebeles used sanitary practices as management measurements but they not implemented it properly, instead, they were expecting chemical control from concerned body and others farmers were not know as the cause of the problem is disease case or BW (46\%). Most farmers or $54 \%$ of interviewed believed that it is due to disease cause and its dissemination is by farming tools and browsing animals that are the most important factor, play major role in dissemination of the pathogen in their fields. Generally, the phytosanitary measures will minimize the EBW disease severity. The results of this survey was agreed with the earlier studies of Million, about $71 \%$ of the farmers reported that careful application of sanitary control measures helps to control EBW. An EBW disease sanitary management measure that helps to prevent reduce or eliminate the spread of $\mathrm{Xcm}$ disease in the field was summarized as follows.

- Avoiding source of inoculum by uprooting the diseased Enset plants and burring in the pit or burning it.

- Flaming the Enset cutting/working tools after use.

- Preventing animals (wild and livestock) from browsing.

- The use of disease free suckers as planting material.

- Cleaning and flaming of equipment that has come in contact with diseased plants and

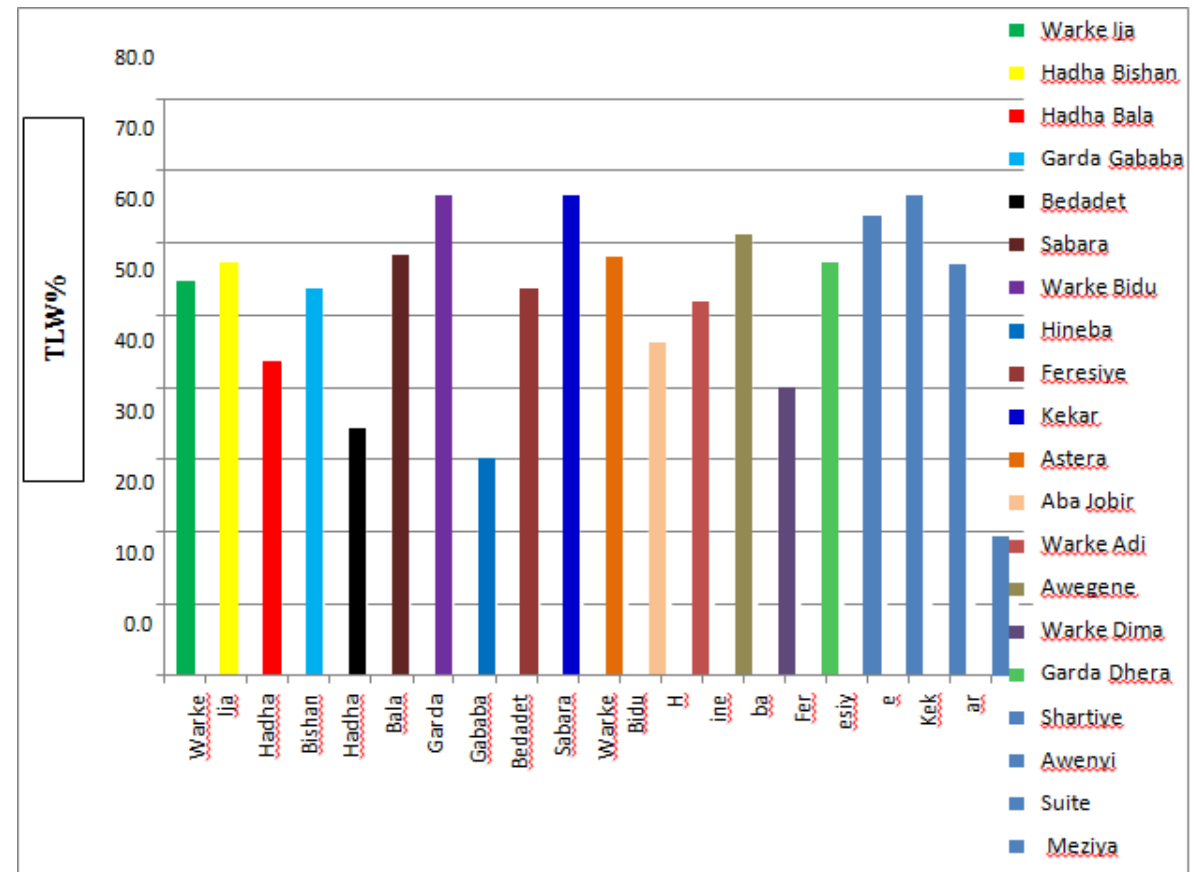

Figure 7: Percentage of total leaves wilted in Enset clones after artificial inoculation with $\mathrm{Xcm}$. 
- Rotations of crops, if the damage is severe were also identified during Enset bacterial wilt disease management assessment from the users point of view that was similarly reported by Brandt et al. [4].

Such measures should be taken in a manner of campaign and as regular practices in all Enset-growing areas. During survey, these practices were conducted in above mentioned districts, some farmers' also practice of tying down the leaves, allowing the diseased plants to dry and then burning as a sanitary control practice (Figure 7). It could be prevent contamination of adjacent plants that could occur during the recommended practices of removal of diseased plants. All respondents agreed that flaming of the Enset cutting/working tools after using them on diseased plant, uprooting and discarding of infected plant is a major control measures, while by contrast, some farmers are tie the animals in the infested field carelessly which contribute to the dissemination of Enset bacterial wilt from infested area to un-infested area. Additionally, they are not practice flaming contaminated farming tools before cutting healthy leaves for different purposes. Farmers traditionally fencing and digging deep ditch around the Enset farm to prevent the movement of animals (domestic and wild) into the Enset field, and traps for catching them. An animals that feed on the corms such as the mole rat and porcupine, not only disseminates the disease but, also one porcupine especially at one night can potentially feed healthy 3-5 Enset plants per field per day, which decline the production and productivity (Figure 8). Additionally, porcupines can choice of Enset plants as human beings that prefer for corm/amicho due to its sweetness. Contrarily, Feresiye and Shertiye corm is due to its bitter cannot eaten by porcupine which is advantages was identified during assessment of Enset producers practice for the management of EBW that further used in integrated management of the target disease [29,30].

\section{Conclusions}

In the study of evaluation of 20 Enset clones resistance/tolerance to $X \mathrm{~cm}$ using artificial inoculation under pot culture condition, among all "Meziya" was found to have the lowest percentage of disease incidence (19.31\%) followed by "Hiniba" (30.18\%) and "Bedadet" (34.26\%) Enset clones. The Enset clones, "Meziya", "Hineba", "Bedadet" and "Warke Dima" have exhibited better resistant/ tolerant against Enset bacterial wilt. Hence, "Meziya", "Hineba", "Bedadet" and "Warke Dima" Enset clones could be considered as most tolerant clones to the pathogen and those clones can be used as a bacterial wilt management component. Developing and use of resistant/tolerant Enset clones is one of the best approaches in the management of EBW, cheaper to the farmers and safer to environments. The Enset clones, "Warke bidu", "Awenyi", and "Kekar" showed $100 \%$ disease symptoms at 30 days after inoculation and could, hence be used as susceptible checks in future screening
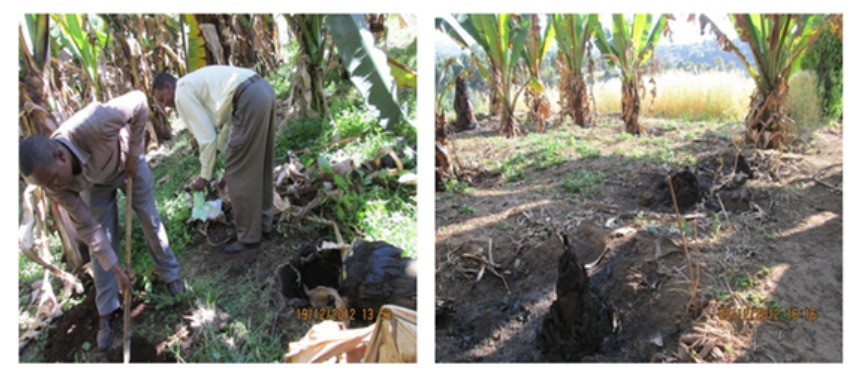

Figure 8: Farmers" practices to avoided source of Enset bacterial wilt pathogen inoculum through burring and burning as sanitary measures. trials. This study shows that Enset clones vary in their reaction to EBW. The farmers have also learned a lot from the collaborative experiments, they are very sure that the contaminated farming tools are the most important factor, play major role in disseminations of the pathogen in their Enset fields. In these regards use of resistant / tolerant clones along with cultural practices and sanitary control measure is viewed to be the most feasible of the bacterial wilt management. In the future Enset producing farmers should prefer to multiply and plant the above mentioned clones due to its resistance to EBW and its multipurpose day-to-day function. Additionally, the Enset clones that showed a resistant or tolerant reaction to the wilt pathogen should be further evaluated against $X \mathrm{~cm}$ isolate under field conditions. The current work alone cannot be conclusive; it is believed that the results obtained were facilitating further works for the satisfactory control of the bacterial disease of Enset in the country. However, more research is needed considering the various Enset clones from the different Enset-growing regions and the future use of molecular techniques to produce markers linked to tolerance in Enset clones.

\section{References}

1. Westphal E (1975) Agricultural system in Ethiopia. Centre for Agricultura Publishing and Documentation, Agricultural University, Wageningen. The Netherlands.

2. Mesfin T, Gebremedhin WG (2008) Enset: Introduction in Root and Tuber Crops: the untapped resources. Gebremedhin WG, Endale $G$ and Berga L. (eds), EAR, Addis Ababa, 155-156

3. Central Statistics Authority (CSA) (2005) Sample/survey for $1996 / 97$ seasons CSA. Addis Ababa, Ethiopia.

4. Brandt SA, Spring A, Hiesch C, McCabe ST, Endale T, et al. (1997) The tree Against Hunger. Enset- based Agricultural systems in Ethiopia. American Association for the Advancement of Science, with Awassa Agricultural Research Center, Kyota University Center for Africa Area Studies and University of Flora Washington, DC,USA.66.

5. Bezuneh T, Feleke A (1966) the production and utilization of the genus Ensete in Ethiopia. Economic Botany 20: 65-70.

6. Ministry of Agriculture (MOA) (1987) Socio economic evaluation of the curren farming system and land use in Hossana study area. Addis Ababa. Ethiopia.

7. Stanley S (1966) Enset in Ethiopia economy. Ethiopia Geographical 10: 30-37

8. Shigeta M (1990) Folk in-situ conservation of Ensete. African Study Monographs (Kyoto) 10: 93-107.

9. Welde-Tensaye A (1997) The Ecology and Production of Ensete ventricosum in Ethiopia. Doctoral thesis, Swedish University of Agriculture Science, Uppsala, 129.

10. Quimio JA, Tessera M (1996) Diseases of Enset. In: T. Abate, C. Hiebsch and S.Brandt (eds.), Enset-based Sustainable Agriculture in Ethiopia. Proceedings of the First International Workshop on Enset. IAR, Addis Ababa: 188-203.

11. Welde-Michael G (2000) Variations in isolates of Enset wilt pathogen (Xanthomonas campestris pv. musacearum) and reaction of Enset (Ensete ventricosum (Welw.) clones to this disease. M.Sc. Thesis. Alemaya University, Ethiopia, pp. 61.

12. Shank R, Chernet (1996) Mole rats: Another Possible Mode of Spreading Enset Bacterial Wilt, Emergencies Unit For Ethiopia [UNDP-EUE] Development Programme, Addis Ababe, Ethiopia.

13. Anita S, Cifton H, Endale T, Gizachew WM (1996) Enset needs assessment project phase 1 report. Awassa, Ethiopia.

14. Tsegaye B, Tesfaye G, Kidist B, Shiferaw M, Bola F (1998) Study on Coffee and Enset Production Conistraints in Kucha Wereda, Kucha KHC Integerated Development project.

15. Endale T, Million T, Gizachew W (2003) Enset-Based Farming System of Kucha Woreda of Gamo Goffa Zone. SARI 52: 48.

16. Blanchard, Talter (1981) Field and Laboratory Guide to Tree Pathology Academic Press, New York, pp. 285. 
Citation: Hunduma T, Sadessa K, Hilu E, Oli M (2015) Evaluation of Enset Clones Resistance against Enset Bacterial Wilt Disease (Xanthomonas campestris pv. musacearum). J Veterinar Sci Technol 6: 232. doi:10.4172/2157-7579.1000232

17. Schaad NW, Stall RE (1988) Xanthomonas. In: Laboratory guide for Identification of Plant Pathogenic bacteria (2ndedn.) N.W. Schaad. APS Press St. paul, Minnesota.81-84.

18. Fahy PC, Hayward GJ (1983) Plant Bacterial Diseases; A Diagnostic Guide Academic Press, Sydney.

19. Kovacs N (1956) Identification of Pseudomonas Pyocyanea by the oxidase reaction. Nature 178: 703.

20. Sands DC (1990) Physiological Criteria Determinative tests. In: Klement Z, Rudolph K, Sands DC (eds.) Methods in Phytobacteriology ,Akademiai Kiade, Budapast,Hungary

21. He LY, Sequeira L, Kelman A (1983) Cherectersics of strains of Pseudomonas solanacearum from china. Plant Disease 67: 1357-1361.

22. Garrity GM, Bell JA, Lieburn T (1921) Pseudomonadales In: Bergey's Manual of Systematic Bacteriology Pp.323-378.

23. SAS Inistitute Inc. (1997) SAS/STAT User's guide, Cary NC. USA 6: 1167.

24. Dereje A (1985) Studies on the bacterial wilt of Enset (Ensete ventricosum) and prospects for its control. Ethiopian Journal of Agricultural science 7: 1-14.
25. Tsehay M (2009) Studies on genetic and Phenotypic variation between Enset and banana isolates of bacterial wilt pathogen (Xanthomonas campestris pv. Musacearum) in Ethiopia, M.Sc., Thesis, Ambo University, Ambo, Ethiopia.

26. Gizachew WM (2000) Variation in isolates of Enset pathogen (Xanthomonas campestris pv musacearum) and reaction of Enset (Enesete ventricosum) clones to this disease. MSc. Thesis. Alemaya University of Agriculture, Haramaya, Ethiopia.

27. Fikre H, Gizachew W (2007) Evaluation of Enset clone meziya against Enset bacterial wilt. African Crop Science Conference Proceedings 8: 887-890.

28. Welde-Michael G, Bobosha K, Addis T, Blomme G, Mekonnen S, et al. (2008) Evaluation of Enset clones against bacterial Wilt, African Crop Science Journal 16: 89-95.

29. Million T, Eshetu A, Endriase G (2003) Enset-Based Farming systems of Masha Wereda. Shaka Zone. 51: 24-25

30. Million T, Kidist B, Gizachew WM (2003) Enset Bacterial wilt sanitary control in Gurage Zone. Awassa 53: 23. 